\title{
Pengaruh Disiplin, Budaya Organisasi dan Motivasi Kerja terhadap Kinerja Karyawan Perum Bulog Kantor Wilayah Jawa Timur
}

\author{
Nurindah Dwi Antika1, Jojok Dwiridotjahjono² \\ Program Studi Administrasi Bisnis, FISIP, UPN “Veteran” Jawa Timur, \\ 18042010003@student.upnjatim.ac.id11 dwiridotjahjono_jojok@upnjatim.ac.id²
}

\begin{abstract}
Quality human resources are a determining factor in improving the performance of a business organization. The performance of a business organization is largely determined by the performance of its employees, and this is the main reason for this research. This study aims to determine the effect of discipline, organizational culture and work motivation on employee performance. This research approach is a descriptive research with a quantitative approach. The data used in this study are primary data obtained directly from respondents through questionnaires in the field and secondary data obtained in finished form, has been collected and processed by other parties. The number of samples taken in this study were 74 respondents. The data analysis technique used in this research is multiple linear regression. The results of the analysis show that the variables of discipline, organizational culture and work motivation have a significant effect on employee performance both simultaneously and partially. The results of this study indicate that the variables of discipline, organizational culture and work motivation are the determining variables in an effort to improve employee performance
\end{abstract}

Keywords : Disiplin, Budaya Organisasi, Motivasi Kerja, Kinerja Karyawan.

\begin{abstract}
ABSTRAK
Sumber daya manusia yang berkualitas merupakan faktor penentu dalam meningkatkan kinerja suatu organisasi bisnis. Kinerja suatu organisasi bisnis sangat ditentukan oleh kinerja karyawannya, dan inilah yang menjadi alasan utama penelitian ini dilakukan. Penelitian ini bertujuan untuk mengetahui pengaruh disiplin, budaya organisasi dan motivasi kerja terhadap kinerja karyawan. Pendekatan penelitian ini merupakan sebuah penelitian yang bersifat deskriptif dengan pendekatan Kuantitatif. Data yang digunakan dalam penelitian ini adalah data primer yang diperoleh langsung dari responden melalui kuesioner dilapangan serta data sekunder yang diperoleh dalam bentuk sudah jadi, sudah dikumpulkan dan diolah oleh pihak lain. Jumlah sampel yang diambil dalam penelitian ini sebanyak 74 orang responden. Teknik analisis data yg digunakan dalam penelitian ini adalah regresi linier berganda. Hasil analisis menunjukkan bahwa variabel disiplin, budaya organisasi dan motivasi kerja berpengaruh signifikan terhadap kinerja karyawan baik secara simultan dan parsial. Hasil penelitian ini menunjukkan bahwa variabel disiplin, budaya organisasi dan motivasi kerja merupakan variabel penentu dalam upaya meningkatkan kinerja karyawan

Kata Kunci : Disiplin, Budaya Organisasi, Motivasi Kerja, Kinerja Karyawan
\end{abstract}

\section{PENDAHULUAN}

Di era globalisasi persaingan semakin ketat, seluruh aktivitas organisasi harus diselaraskan dengan perkembangan teknologi dan kemampuan manusia,, peran manusia dalam organisasi dapat dikelola melalui Manajemen Sumber Daya Manusia (MSDM), dengan adanya Manajemen Sumber Daya Manusia dapat mendorong terciptanya sumber daya manusia yang berkualitas, sumber daya yang mempunyai kemampuan, sikap, kemauan untuk memberikan kontribusi demi kemajuan 


\section{Reslaj: Relicion Education Social Laa Roiba Journal}

Volume 4 Nomor 3 (2022) 516-527 P-ISSN 2656-274x E-ISSN 2656-4691

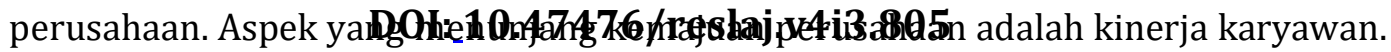
Perusahaan dapat meningkatkan kinerja karyawannya dengan cara menganalisa faktor-faktor yang mempengaruhinya.

Yang pertama yaitu Disiplin Kerja. Disiplin Kerja merupakan tolak ukur karyawan dalam mematuhi peraturan yang sudah ditetapkan sebelumnya. Jika karyawan mempunyai rasa kedisiplinan maka dapat memberikan dampak yang positif bagi perusahaan. Yang kedua yaitu Budaya organisasi. Budaya Organisasi merupakan pedoman bagi perusahaan dalam melakukan segala aktivitas, sehinga secara tidak langsung budaya organisasi mempunyai pengaruh dalam membentuk sikap, perilaku, serta bertanggung jawab karyawan, ada juga faktor lain yaitu motivasi. Motivasi merupakan keinginan yang muncul dalam diri karyawan sehingga menimbulkan semangat tinggi dalam melakukan pekerjaan. Semakin kuat motivasi seseorang, semakin kuat pula usaha karyawan untuk mencapai tujuan perusahaan.

Berdasarkan hasil pengamatan dan wawancara masih banyak permasalahan yang terjadi di Perum BULOG Kantor Wilayah Jawa Timur yang mana berkaitan dengan disiplin kerja. Banyak karyawan yang masih datang terlambat, pulang lebih cepat dari jam kerja, serta karyawan terkadang lalai tidak melakukan scan masuk maupun scan pulang. Berikut disajikan data rekaputasi absensi masuk \& pulang karyawan perum BULOG kantor wilayah jawa timur periode Januari - Agustus 2021

\section{Gambar 1.1}

\begin{tabular}{lcccc}
\hline \multirow{2}{*}{ Bulan } & \multicolumn{3}{c}{ Absensi Masuk \& Pulang } & Jumlah Total \\
\cline { 2 - 4 } & $\begin{array}{c}\text { Datang } \\
\text { Terlambat }\end{array}$ & Pulang Cepat & Lalai Absen & \\
\hline Januari & 155 & 50 & 140 & $76,7 \%$ \\
Februari & 152 & 70 & 145 & $73,9 \%$ \\
Maret & 150 & 55 & 129 & $76,3 \%$ \\
April & 160 & 76 & 145 & $75,5 \%$ \\
Mei & 165 & 82 & 122 & $70,7 \%$ \\
Juni & 170 & 80 & 152 & $75,4 \%$ \\
Juli & 167 & 85 & 136 & $75,1 \%$ \\
Agustus & 155 & 78 & 156 & $77,2 \%$ \\
\hline
\end{tabular}

Meskipun demikian, menurut beberapa sumber, budaya organisasi disana masih dipertahankan dengan baik seperti contohnya setiap hari sebelum dilakukannya aktivitas kerja, pimpinan dan karyawan Perum BULOG selalu dan wajib melaksanakan doa bersama, Selain itu, ada budaya organisasi juga yang tercantum dalam peraturan perusahaan yaitu budaya "AKHLAK". Akan tetapi kenyataanya karyawan menganggap bahwa budaya "AKHLAK". tersebut merupakan standar umum sebuah industry sehingga banyak implementasinya yang belum melekat dalam diri karyawan.

Hal tersebut dibuktikan dari banyaknya karyawan yang tidak disiplin, dan motivasi kerja karyawan yang masih rendah. Karyawan menganggap bahwa perusahaan belum memberikan fasilitas kerja dengan baik, seperti ruangan kerja masih dijadikan satu dengan divisi lain, Berdasarkan permasalahan-permasalahan di atas, peneliti tertarik untuk meneliti permasalahan tersebut dengan judul "Pengaruh Disiplin, Budaya Organisasi dan Motivasi Kerja Terhadap Kinerja Karyawan Perum BULOG Kantor Wilayah Jawa Timur"

TINJAUAN PUSTAKA

Disiplin 


\section{Reslaj: Relicion Education Social Laa Roiba Journal}

\section{Volume 4 Nomor 3 (2022) 516-527 P-ISSN 2656-274x E-ISSN 2656-4691}

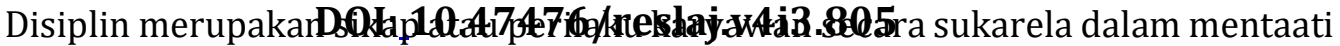
peraturan atau prosedur kerja. Menurut Sinambela (2018), disiplin merupakan sikap, tingkah laku dan perbuatan yang sesuai dengan peraturan perusahaan baik yang tertulis maupun yang tidak tertulis. Dengan adanya disiplin kerja dapat membantu terpeliharanya tata tertib dan kelancaran pelaksanaan tugas. Sedangkan bagi karyawan akan diperoleh suasana kerja yang menyenangkan sehingga timbul semangat kerja untuk menyelesaikan pekerjaan. Menurut Dewi \& Harjoyo (2019:96) Berikut beberapa indikator disiplin kerja antara lain :

1. Disiplin Waktu.

Diartikan sebagai sikap/tingkah laku yang menunjukkan ketaatan terhadap jam kerja yang meliputi: kehadiran dan kepatuhan karyawan pada jam kerja, pelaksanaan tugas dengan tepat waktu dan benar.

2. Disiplin Peraturan.

Peraturan maupan tata tertib yang tertulis dan yangtidak tertulis dibuat agar tujuan suatu organisasi dapat dicapai dengan baik.Untuk itu dibutuhkan sikap setia dari karyawan terhadap komitmen yangtelah ditetapkan tersebut.

3. Disiplin Tanggung Jawab.

Salah satu wujud tanggung jawab karyawanadalah penggunaan dan pemeliharaan peralatan yang sebaik-baiknyasehingga dapat menunjang kegiatan kantor berjalan dengan lancar.

\section{Budaya Organisasi}

Budaya Organisasi merupakan pedoman atau identitas bagi perusahaan dalam melakukan segala aktivitas yang mengacu pada nilai dan pola keyakinan suatu organisasi. Menurut Enny (2019:52) budaya organisasi adalah suatu sistem nilai yang diperoleh dan dikembangkan oleh organisasi menjadi aturan atau pedoman dalam berfikir dan bertindak. Sedangkan menurut Tuala (2020:03) budaya organisasi adalah pola asumsi-asumsi dasar yang berkenaan dengan kepercayaan, nilai-nilai, dan tingkah laku yang dikembangkan oleh suatu organisasi untuk mencapai tujuan. Menurut Tuala (2020:04) Karakteristik budaya organisasi adalah sebagai berikut:

1. Inovasi Dan Pengambilan Resiko, yaitu sejauh mana karyawan didorong untuk inovatif dan berani dalm mengambil resiko

2. Perhatian, yaitu sejauh mana karyawan memperlihatkan kecermatan, dan perhatian terhadap hal yang rinci.

3. Orientasi Hasil, yaitu sejauh mana pimpinan memusatkan perhatian pada hasil, bukannya pada teknik mencapai hasil.

4. Orientasi Orang, yaitu seberapa jauh keputusan manajemen mempengaruhi orang yang ada dalam organisasi.

5. Orientasi Tim, yaitu sejauh mana kegiatan kerja diorganisasikan dalam tim-tim kerja, bukannya individu

6. Kegresifan, sejauh mana orang-orang itu agresif dan kompetitif dan bukannya santai-santai.

7. Kemantapan/Stabilitas, yaitu kadar seberapa jauh keputusan dan tindakan organisasi menekankan usaha untuk mempertahankan status quo.

\section{Motivasi Kerja}

Setiap perusahaan pasti menginginkan agar tujuan perusahaannya dapat tercapai. Oleh karena itu, hal tersebut bisa dilakukan dengan cara memotivasi para karyawan. Menurut Marliani (2018) dalam Safitri (2018:5) mengatakan bahwa motivasi menjadi penting dalam bekerja karena tanpa motivasi kerja yang kuat dalam diri, maka bekerja mudah tergoyahkan. Artinya bahwa motivasi kerja adalah sesuatu yang dapat menimbulkan semangat tinggi dalam melakukan pekerjaan, tanpa adanya motivasi maka pekerjaan akan terasa sia-sia. Menurut Tahir (2017:116) Terdapat beberapa bentuk kegiatan motivasi kerja terhadap karyawan yaitu sebagai berikut : 


\section{Reslaj: Relicion Education Social Laa Roiba Jourual}

Volume 4 Nomor 3 (2022) 516-527 P-ISSN 2656-274x E-ISSN 2656-4691

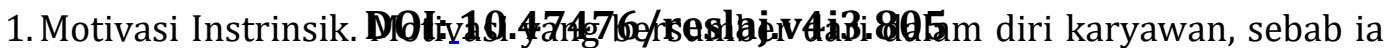
mersa pekerjaan yang dikerjaan mampu memenuhi kebutuhan, atau memungkinkan mencapai suatu tujuan di masa depan.

2. Motivasi Ekstrinsik. Motivasi yang bersumber dari luar diri pekerja. Suatu kondisi yang mengharuskannya melaksanakan pekerjaan secara maksimal. Misalnya berdedikasi tinggi dalam bekerja karena upah gaji yang tinggi.

\section{Kinerja Karyawan}

Kinerja berasal dari kata job performance yang berarti prestasi kerja sesungguhnya yang dicapai oleh seseorang. Menurut Luthans, 2005:165 dalam Masram \& Mu'ah (2017:148) kinerja adalah hasil kerja secara kualitas dan kuantitas yang dicapai oleh karyawan sesuai dengan tanggung jawab yang diberikan. Artinya bahwa kinerja adalah hasil kerja dan perilaku kerja yang telah dicapai dalam menyelesaikan tugas dan tanggung jawab yang diberikan dalam satu periode tertentu. Kinerja selalu berhubungan dengan karyawan, sehingga banyak orang selalu menyebutnya dengan Kinerja Karyawan. Menurut Bangun (2012:233) dalam Asnawi (2019:14) indikator-indikator untuk mengukur kinerja karyawan adalah sebagai berikut:

1. Kualitas. Kualitas kerja diukur dari persepsi karyawan terhadap kualitas pekerjaan yang dihasilkan serta kesempurnaan tugas.

2. Kuantitas. Merupakan jumlah yang dihasilkan dinyatakan dalam istilah seperti jumlah unit, jumlah siklus aktivitas yang diselesaikan.

3. Ketepatan Waktu. Merupakan tingkat aktivitas diselesaikan pada awal waktu yang dinyatakan, dilihat dari sudut koordinasi dengan hasil output serta memaksimalkan waktu yang tersedia untuk aktivitas lain.

4. Efektivitas. Merupakan tingkat penggunaan sumber daya organisasi (tenaga, uang, teknologi, bahan baku) dimaksimalkan dengan maksud menaikkan hasil dari setiap unit dalam penggunaan sumber daya.

\section{Model Hipotesis}

\section{Gambar 1.2 \\ Kerangka Berfikir}

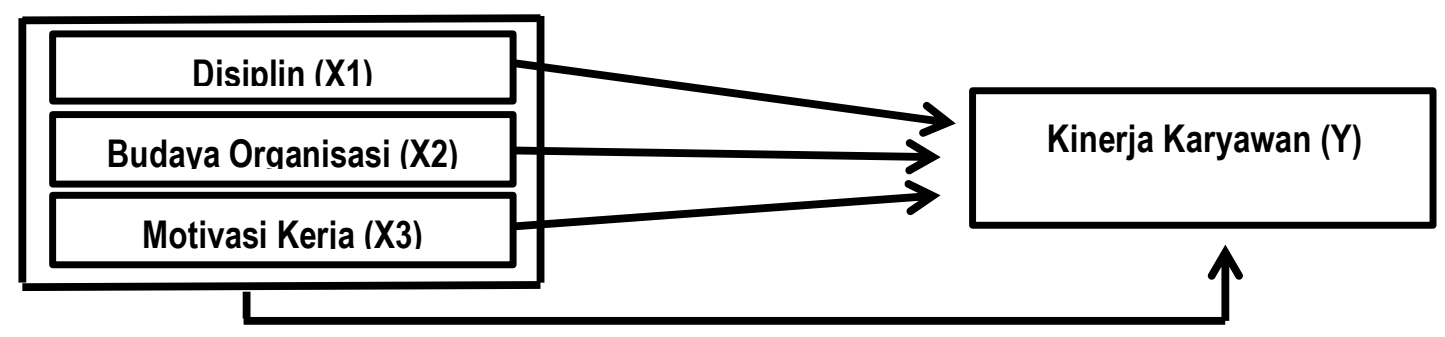

Berdasarkan model hipotesis, maka hipotesis dalam penelitian ini adalah:

H1 : Variabel displin, budaya organisasi dan motivasi kerja secara simultan berpengaruh

signifikan terhadap kinerja karyawan

H2 : Variabel disiplin secara parsial berpengaruh signifikan terhadap kinerja karyawan

H3 : Variabel budaya organisasi secara parsial berpengaruh signifikan terhadap kinerja

karyawan

H4 : Variabel motivasi kerja secara parsial berpengaruh signifikan terhadap kinerja karyawan 


\section{Reslaj: Religion Education Social Laa Roiba Journal}

Volume 4 Nomor 3 (2022) 516-527 P-ISSN 2656-274x E-ISSN 2656-4691

DOI:_10.47476/reslaj.v4i3.805

METODE PENELITIAN

Jenis Dan Lokasi Penelitian

Pendekatan yg digunakan dalam penelitian ini adalah penelitian kuantitatif. Penelitian ini dilakukan di Perum BULOG Kantor Wilayah Jawa Timur. Lokasi perusahaan ini terletak di Jl. Ahmad Yani No. 146-148, Gayungan, Kec. Gayungan, Kota Surabaya, Jawa Timur 60235.

Populasi Sampel

Dalam penelitian ini yang menjadi populasi adalah seluruh karyawan Perum BULOG Kantor Wilayah Jawa Timur sejumlah 74 karyawan. Teknik sampling yang digunakan adalah sampel sampling jenuh yaitu seluruh karyawan di Perum BULOG Kantor Wilayah Jawa Timur. Dan semuanya dijadikan sampel dalam penelitian ini Pengumpulan Data

Pengumpulan data penelitian ini menggunakan Instrument pengumpulan data yaitu metode kuesioner. Selain pengumpulan data secara langsung ke responden juga dilakukan pengumpulan data dengan teknik documenter untuk menunjang analisis penelitian..

\section{Pengujian Instrumen Data}

Pengujian instrumen menggunakan uji validitas dan reliabilitas. Data dikatakan valid apabila nilai $r$ hitung $>r$ tabel. Sedangkan data dikatakan reabil apabila nilai Cronbach Alpha dari variabel variabel tersebut lebih besar daripada 0,6, atau instrument yang dipakai sudah tepat dan layak untuk diteruskan ke pengujian berikutnya.

\section{Pengujian Asumsi Klasik}

Pengujian asumsi klasik ada 4 yaitu uji normalitas. Uji Normalitas digunakan untuk mengetahui distribusi data. Apakah mengikuti distribusi normal atau tidak. Uji multikolinieritas. Uji Multikolinearitas bertujuan untuk mengetahui nilai variance inflation factor (VIF). Jika nilai VIF > 10 maka tidak terjadi multikolinearitas, dan sebaliknya. Uji Heteroskedastistas. Pengujian ini dilakukan untuk merespon variabel $\mathrm{x}$ dengan absolut unstandardiez residual regresi. Apabila hasil uji di atas level signifikan $(r>0,05)$ berarti tidak ada heteroskedastisitas dan sebaliknya. Dan Uji Autokorelasi. Menguji autokorelasi dalam suatu metode yang bertujuan untuk mengetahui ada tidaknya korelasi antara variabel pengganggu pada periode tertentu dengan variabel sebelumnya, dengan nilai Durbin Watson

\section{Analisis Data}

Analisis data yang digunakan dalam penelitian ini adalah analisis regresi linier berganda. Pengujian hipotesis dilakukan dengan uji F dan uji t u pembuktian hipotesis yang diajukan

\section{HASIL DAN PEMBAHASAN}

\section{Hasil}

\section{Uji Validitas}

Uji validitas dilakukan untuk mengetahui valid atau tidaknya kuesionerUntuk mengetahui tanggapan 74 responden tentang analisis pengaruh disiplin, budaya organisasi dan motivasi kerja terhadap kinerja karyawan. Uji validitas digunakan dengan bantuan software SPSS 20 .

\section{Tabel 1.1 Hasil Uji Validitas}




\section{Reslaj: Religion Education Social Laa Roiba Jourual}

Volume 4 Nomor 3 (2022) 516-527 P-ISSN 2656-274x E-ISSN 2656-4691

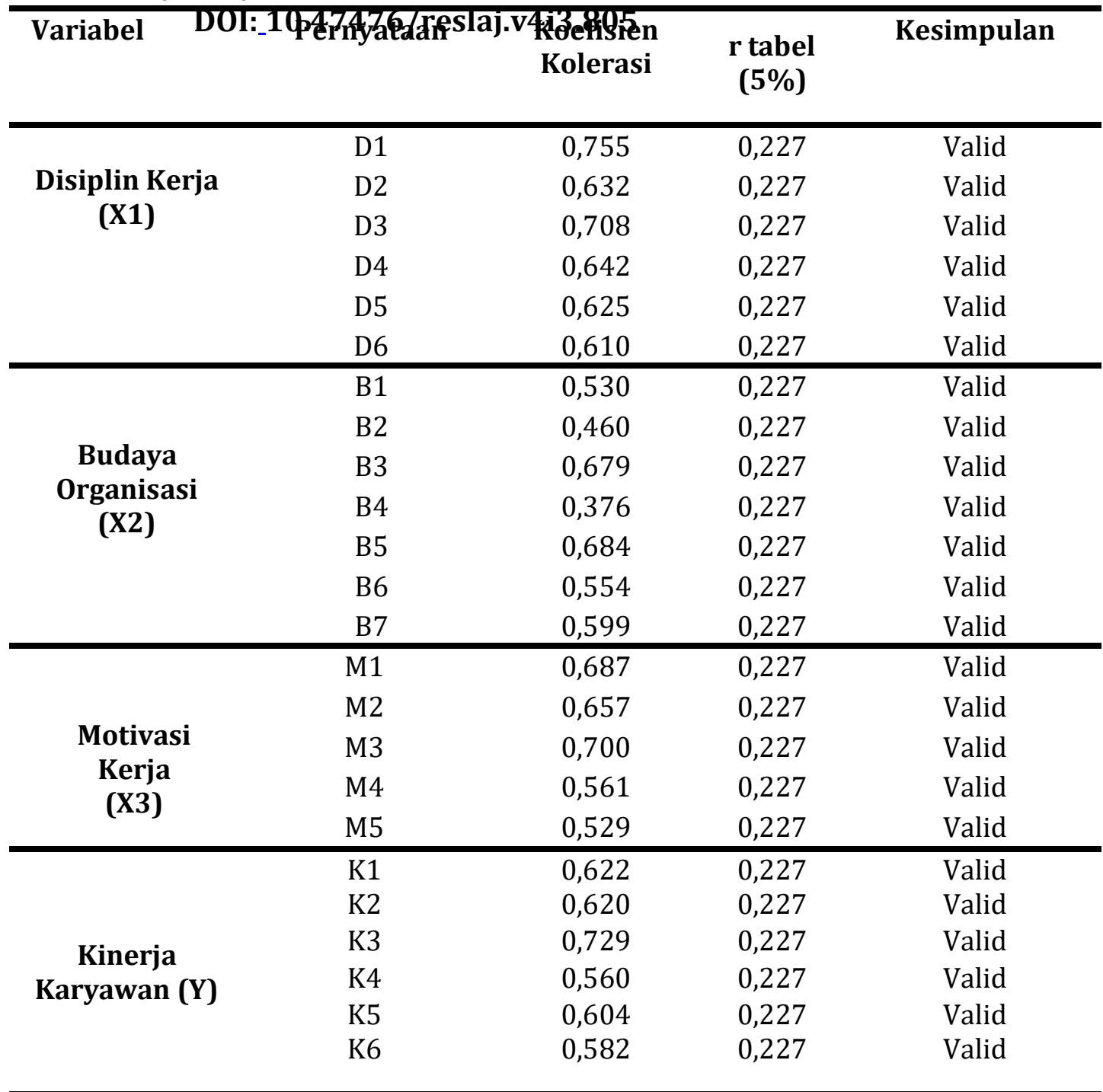

\section{Sumber : Data Primer Setelah Diolah}

Berdasarkan data diatas menunjukan bahwa nilai korelasi lebih besar dari $r$ tabel, sehingga dinyatakan bahwa semua variabel bebas maupun terikat menunjukan data yang valid.

\section{Uji Reliabilitas}

Uji Reabilitas digunakan untuk mengetahui apakah pertanyaan yang diajukan terhadap responden akan memberikan jawaban yang cenderung konsisten. Hasil uji reabilitas terhadap variabel dapat terlihat pada tabel berikut:

Tabel 1.2 Hasil Uji Reabilitas

\begin{tabular}{lccc}
\hline \multicolumn{1}{c}{ Variabel } & Cronbach'Alpha & Alpha & Kesimpulan \\
\hline Displin Kerja (X1) & 0,741 & 0,6 & Reliabel \\
\hline $\begin{array}{l}\text { Budaya Organisasi } \\
\text { (X2) }\end{array}$ & 0,626 & 0,6 & Reliabel \\
\hline Motivasi Kerja (X3) & 0,618 & 0,6 & Reliabel \\
\hline Kinerja Karyawan (Y) & 0,677 & 0,6 & Reliabel \\
\hline
\end{tabular}

Sumber : Data Primer Setelah Diolah 


\section{Reslaj: Relicion Education Social Laa Roiba Jourual}

Volume 4 Nomor 3 (2022) 516-527 P-ISSN 2656-274x E-ISSN 2656-4691

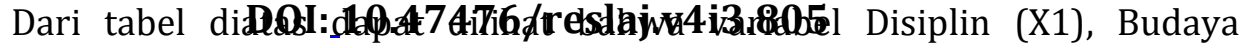
Organisasi (X2), Motivasi Kerja (X3) dan Kinerja Karyawan (Y) telah reliabel. Karena semua nilai alpha ( $\mathrm{r}$ hitung) lebih besar dari 0,6. Maka dalam penelitian ini seluruh variabel dinyatakan reliabel.

\section{Uji Normalitas}

Uji normalitas menggunakan hasil uji kolmogorov-smirnov dapat dilihat dari tabel dibawah ini

Tabel 1.3 Hasil Uji Normalitas

\begin{tabular}{llr}
\hline \multicolumn{2}{c}{ One-Sample Kolmogorov-Smirnov Test } & Unstandardized \\
& & Residual \\
$\mathrm{N}$ & Mean & 74 \\
Normal Parameters & a,b & $0 \mathrm{E}-7$ \\
& Std. Deviation & 1.61126713 \\
Most Extreme Differences & Absolute & .087 \\
& Positive & .087 \\
& Negative & -.035 \\
Kolmogorov-Smirnov Z & & .745 \\
Asymp. Sig. (2-tailed) & & .636 \\
a. Test distribution is Normal. & \\
b. Calculated from data. & \\
\hline
\end{tabular}

Dari tabel tersebut dapat dijelaskan bahwa hasil uji Kolmogorov-Smirnov memang terbukti bahwa nilai residual mengikuti sebaran normal karena Asymp. Sig (2-tailed) $=0,636>0,05$. Dan berikut meupakan gambar Hasil Uji Pilot Project P-Plot

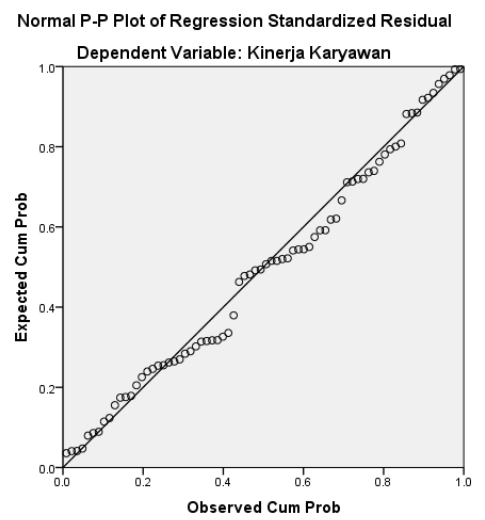

\section{Hasil Uji Hipotesis}

A. Pengaruh secara Simultan atau Uji (f)

Uji F digunakan untuk menguji variabel bebas secara simultan mempunyai pengaruh signifikan atau tidak signifikan dengan variabel terikat.

Tabel 1.5 Hasil Uji Simultan

\begin{tabular}{llrrlrll}
\hline \multirow{2}{*}{ Model } & & \multicolumn{9}{c}{ ANOVA $^{\mathbf{a}}$} & & \multirow{2}{*}{ Sig. } \\
\multirow{2}{*}{1} & & \multicolumn{1}{l}{ Sum of } & Df & Mean & F & & \\
& Regression & 411.938 & 3 & 137.313 & 50.717 & $.000^{\mathrm{b}}$ \\
& Residual & 189.521 & 70 & 2.707 & & \\
& Total & 601.459 & 73 & & & \\
\hline
\end{tabular}




\section{Reslaj: Relicion Education Social Laa Roiba Journal}

Volume 4 Nomor 3 (2022) 516-527 P-ISSN 2656-274x E-ISSN 2656-4691

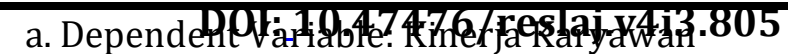

b. Predictors: (Constant), Motivasi Kerja, Budaya Organisasi, Disiplin

\section{Sumber : Data Primer Setelah Diolah}

Langkah-langkah pengujian :

a) Penentuan penerimaan dan penolakan :•

1. Jika P-value $>\mathrm{a}=0,05$ maka H0 diterima dan $\mathrm{H} 1$ ditolak. Hal ini berarti variabel bebas secara simultan tidak mempunyai pengaruh yang signifikan dengan variabel terikat.

2. Jika P-value $<\mathrm{a}=0,05$ maka $\mathrm{H} 0$ ditolak dan $\mathrm{H} 1$ diterima. Hal ini berarti variabel bebas secara simultan memiliki pengaruh yangsignifikan dengan variabel terikat.•

b) Hasil pengujian :

Diketahui $=$ jumlah reponden $(n)=74$, jumlah variabel $(k)=3$. Tingkat kesalahan (a) $=5 \%$.

Rumus Ftabel

$$
\begin{aligned}
\text { Ftabel } & =(\mathrm{k} ; \mathrm{n}-\mathrm{k}) \\
& =(3 ; 74-3) \\
& =(3 ; 71) \\
& =2.73
\end{aligned}
$$

maka Ftabel yang digunakan adalah t $0.05(3 ; 71)=2.73$.

c) Berdasarkan hasil data tabel annova diatas dapat dilihat bahwa nilai signifikansi $0,000<0,05$

d) Kesimpulan : Berdasarkan hasil pengolahan data untuk melakukan uji hipotesis, diketahui $\mathrm{F}$ hitung adalah sebesar 50,717 dengan nilai signifikansi sebesar 0,000 lebih kecil <0,05. Kesimpulannya disiplin, budaya organisasi dan motivasi kerja secara simultan berpengaruh terhadap kinerja karyawan pada Perum BULOG Kantor Wilayah Jawa

\begin{tabular}{|c|c|c|c|c|c|c|}
\hline \multirow{2}{*}{\multicolumn{2}{|c|}{ Model }} & \multicolumn{2}{|c|}{$\begin{array}{l}\text { Unstandardized } \\
\text { Coefficients }\end{array}$} & \multirow{2}{*}{$\begin{array}{l}\text { Standardiz } \\
\text { ed } \\
\text { Coefficient } \\
\text { s } \\
\text { Beta }\end{array}$} & \multirow[t]{2}{*}{$\mathrm{t}$} & \multirow[t]{2}{*}{ Sig. } \\
\hline & & B & $\begin{array}{l}\text { Std. } \\
\text { Erro } \\
\text { r }\end{array}$ & & & \\
\hline 1 & (Constant) & 1.178 & $\begin{array}{r}1.88 \\
5\end{array}$ & & .625 & .534 \\
\hline & Disiplin (X1) & .207 & .057 & .269 & 3.640 & .001 \\
\hline & Budaya Organisasi (X2) & .325 & .062 & .393 & 5.226 & .000 \\
\hline & Motivasi Kerja (X3) & .437 & .085 & .414 & 5.172 & .000 \\
\hline & ependent Variable: Kine & Karyawa & & & & \\
\hline
\end{tabular}
Timur.

\section{B. Pengaruh secara parsial atau Uji (t)}

Tabel 1.6 Hasil Uji Parsial

Berdasarkan Hasil Tabel dengan mengamati baris,kolom t dan sig maka bisa diberikan penjelasan sebagai berikut :

1. Uji parsial antara variabel disiplin (X1) terhadap kinerja karyawan

(Y) 


\section{Reslaj: Religion Education Social Laa Roiba Journal}

Volume 4 Nomor 3 (2022) 516-527 P-ISSN 2656-274x E-ISSN 2656-4691

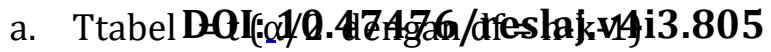

$$
\begin{aligned}
\mathrm{t} & =(0,05 / 2 \text { dengan } \mathrm{df}=(74-3-1) \\
\mathrm{t} & =(0,025 \text { dengan } \mathrm{df}=70) \\
& =1.997
\end{aligned}
$$

b. Nilai signifikansi $0,001<0,05$

c. thitung $>$ ttabel $=3.640>1.997$

d. Kesimpulan : Berdasarkan hasil pengolahan data untuk uji hipotesis, diketahui bahwa nilai thitung sebesar 3.640 dengan nilai signifikasi sebesar 0,001 lebih kecil < 0,05. Kesimpulannya disiplin secara parsial berpengaruh signifikan terhadap kinerja karyawan pada Perum BULOG Kantor Wilayah Jawa Timur.

2. Uji parsial antara variabel budaya organisasi (X2) terhadap kinerja karyawan (Y)

$$
\text { a. } \begin{aligned}
\text { Ttabel } & =\mathrm{t}(\alpha / 2 \text { dengan } \mathrm{df}=\mathrm{n}-\mathrm{k}-1) \\
& =1.997
\end{aligned}
$$

b. Nilai signifikansi $0,000<0,05$

c. thitung $>$ ttabel $=5.226>1.997$

d. Kesimpulan : Berdasarkan hasil pengolahan data untuk uji hipotesis, diketahui bahwa nilai thitung sebesar 5.226 dengan nilai signifikasi sebesar 0,000 lebih kecil $<0,05$. Kesimpulannya budaya organisasi secara parsial berpengaruh signifikan terhadap kinerja karyawan pada Perum BULOG Kantor Wilayah Jawa Timur.

3. Uji parsial antara variabel Displin Kerja (X3) terhadap kinerja karyawan (Y)
a. $\quad$ Ttabel $=\mathrm{t}(\alpha / 2$ dengan $\mathrm{df}=\mathrm{n}-\mathrm{k}-1)$

$$
=1.997
$$
b. Nilai signifikansi $0,001<0,05$
c. thitung $>$ ttabel $=5.172>1.997$
d. Kesimpulan : Berdasarkan hasil pengolahan data untuk uji hipotesis, diketahui bahwa nilai thitung sebesar 5.172 dengan nilai signifikasi sebesar 0,000 lebih kecil < 0,05. Kesimpulannya motivasi kerja secara parsial berpengaruh signifikan terhadap kinerja karyawan pada Perum BULOG Kantor Wilayah Jawa Timur.

\section{Pembahasan}

\section{A. Pengaruh secara simultan atau uji (F)}

1. Pengaruh Disiplin, Budaya Organisasi, Dan Motivasi Kerja Secara Simultan Terhadap Kinerja Karyawan

Berdasarkan hasil pengolahan data, diketahui nilai $\mathrm{F}$ hitung adalah sebesar 50,717 dengan nilai signifikansi sebesar 0,000 lebih kecil < 0,05. Kesimpulannya disiplin, budaya organisasi dan motivasi kerja secara simultan berpengaruh terhadap kinerja karyawan Pada Perum BULOG Kantor Wilayah Jawa Timur. Hasil analisis ini sesuai dengan apa yang dihipotesiskan oleh peneliti, dan Hasil dari penelitian ini didukung penelitian yang sebelumnya oleh Virsa Sari Widuri dkk (2020) yang menyatakan bahwa disiplin, budaya organisasi dan motivasi kerja berpengaruh signifikan terhadap kinerja karyawan. Artinya jika perusahaan yang mempunyai tingkat disiplin yang baik, nantinya akan dapat membentuk budaya organisasi yang harmonis, serta hal tersebut juga akan dapat menciptakan motivasi kerja tumbuh rangsangan dalam diri karyawan untuk melakukan tindakan kerja yang baik. Sehingga dapat disimpulkan bahwa jika perusahaan berhasil menerapkan disiplin, 


\section{Reslaj: Relicion Education Social Laa Roiba Journal}

Volume 4 Nomor 3 (2022) 516-527 P-ISSN 2656-274x E-ISSN 2656-4691

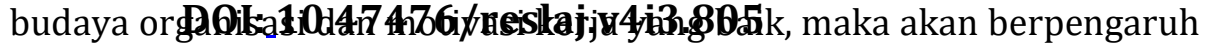
baik pula terhadap kinerja karyawan baik secara kerja individu atau kelompok.

B. Pengaruh secara parsial atau uji $(t)$

1) Pengaruh Disiplin (X1) Terhadap Kinerja Karyawan (Y)

Berdasarkan hasil pengolahan data dan analisis data, diketahui bahwa nilai thitung sebesar 3.640 dengan nilai signifikasi sebesar 0,001 lebih kecil < 0,05. Sehingga kesimpulannya disiplin secara parsial berpengaruh signifikan terhadap kinerja karyawan. Hasil analisis ini sesuai dengan apa yang dihipotesiskan oleh peneliti dan Hasil penelitian ini didukung oleh penelitian yang sudah dilakukan sebelumnya oleh Nurindah dkk (2021) menyatakan bahwa variabel disiplin kerja berpengaruh signifikan terhadap kinerja karyawan. Artinya disiplin penting sebab pelaksanaan kedisiplinan dalam perusahaan akan dapat membantu mengarahkan karyawan menjalankan pekerjaan sesuai dengan aturan-aturan.

2) Pengaruh Budaya organisasi (X2) Terhadap Kinerja Karyawan (Y)

Berdasarkan hasil pengolahan dan analisis data, diketahui bahwa nilai thitung sebesar 5.226 dengan nilai signifikasi sebesar 0,000 lebih kecil $<0,05$. Sehingga kesimpulannya budaya organisasi secara parsial berpengaruh signifikan terhadap kinerja karyawan. Hasil analisis ini sesuai dengan apa yang dihipotesiskan oleh peneliti, dan Hasil penelitian ini didukung oleh penelitian yang dilakukan sebelumnya oleh Gaby I Rumangit dkk (2019) yang menunjukkan adanya pengaruh positif dan signifikan antara budaya organisasi terhadap kinerja karyawan. Artinya bahwa terdapat hubungan langsung yang signifikan antara kinerja karyawan yaitu semakin tinggi persepsi karyawan mengenai budaya organisasi akan semakin tinggi tingkat kinerja karyawan. Budaya organisasi memberikan dampak positif bagi internal perusahaan maupun karyawan secara individu, karena budaya organisasi adalah karakter organisasi yang memungkinkan para anggota organisasi mengidentifikasi dirinya sebagai bagian dari organisasi.

3) Pengaruh Motivasi Kerja (X3) Terhadap Kinerja Karyawan (Y)

Berdasarkan hasil pengolahan dan analisis data, diketahui bahwa nilai thitung sebesar 5.172 dengan nilai signifikasi sebesar 0,000 lebih kecil $<0,05$. Sehingga kesimpulannya motivasi kerja secara parsial berpengaruh signifikan terhadap kinerja karyawan. Hasil analisis ini sesuai dengan apa yang dihipotesiskan oleh peneliti, Hasil penelitian ini juga didukung dengan penelitian yang sudah dilakukan sebelumnya oleh Nurindah dkk (2021) yang menyatakan bahwa variabel motivasi kerja berpengaruh signifikan terhadap kinerja karyawan. Artinya motivasi kerja merupakan unsur penting, sebab adanya motivasi dapat menciptakan semangat kerja, menumbuhkan rangsangan untuk bisa bekerja maksimal. Apabila kebutuhannya terpenuhi maka karyawan tersebut akan memperlihatkan perilaku kegembiraan dalam bekerja sebagai wujud rasa puas, begitu juga sebaliknya.

\section{KESIMPULAN}

Berdasarkan hasil analisis dan pembahasan yang diuraikan, maka dapat ditarik kesimpulan sebagai berikut :

1. Berdasarkan hasil analisis data, pengaruh disiplin (X1) dan budaya organisasi (X2) dan motivasi kerja (X3) secara simultan berpengaruh signifikan terhadap 


\section{Reslaj: Relicion Education Social Laa Roiba Journal}

Volume 4 Nomor 3 (2022) 516-527 P-ISSN 2656-274x E-ISSN 2656-4691

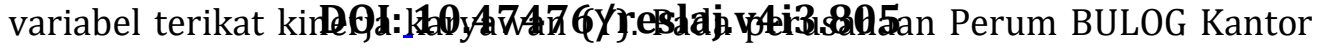
Wilayah Jawa Timur. Artinya jika perusahaan jika perusahaan berhasil menerapkan disiplin, budaya organisasi dan motivasi kerja yang baik, maka akan berpengaruh baik pula terhadap kinerja karyawan baik secara kerja individu atau kelompok.

2. Berdasarkan hasil analisis data, pengaruh disiplin (X1) secara parsial berpengaruh signifikan terhadap kinerja karyawan (Y) Perum BULOG Kantor Wilayah Jawa Timur, artinya disiplin penting sebab pelaksanaan kedisiplinan dalam perusahaan akan dapat membantu mengarahkan karyawan menjalankan pekerjaan sesuai dengan aturan-aturan yang disepakati sehingga hal tersebut juga berdampak pada peningkatan kinerja karyawan.

3. Berdasarkan hasil analisis data, pengaruh budaya organisasi secara parsial berpengaruh signifikan terhadap kinerja karyawan Perum BULOG Kantor Wilayah Jawa Timur, artinya terdapat hubungan langsung yang signifikan antara kinerja karyawan artinya semakin tinggi persepsi karyawan mengenai budaya organisasi akan semakin tinggi tingkat kinerja karyawan.

4. Berdasarkan hasil analisis data, pengaruh motivasi kerja secara parsial berpengaruh signifikan terhadap kinerja karyawan Perum BULOG Kantor Wilayah Jawa Timur, artinya Motivasi kerja merupakan unsur penting sebab adanya motivasi dapat menciptakan semangat kerja, menumbuhkan rangsangan untuk bisa bekerja maksimal. Terdapat hubungan langsung yang signifikan antara motivasi kerja dengan kinerja artinya motivasi kerja yang semakin tinggi maka kinerja karyawan semakin meningkat. .

\section{Saran}

1. Agar terciptanya kinerja karyawan yang tinggi, maka perusahaan perlu memperhatikan, meningkatkan dan menitik beratkan mengenai faktor-faktor yang mempengaruhi kinerja tersebut yaitu motivasi, disiplin kerja dan budaya organisasi.

2. Perusahaan harus lebih memperhatikan masalah disiplin, karna disiplin mempunyai pengaruh yang paling dominan terhadap kinerja karyawan. seperti, ketepatan waktu, tingkat pelanggaran. maka dari itu pihak perusahaan harus lebih meningkatkan sanksi hingga melakukan pendisiplinan

3. Perusahaan harus lebih memperhatikan masalah motivasi kerja, sebab motivasi bukan hanya muncul dari dalam diri karyawan karyawan itu sendiri, akan tetapi terkadang karyawan mengharapkan motivasi yang lebih dari perusahaan dan juga suasana lingkungan untuk menunjang semangat kerja karyawan dalam bekerja.

4. Perusahaan harus memastikan bahwa karyawan merasa puas akan pekerjaan yang ia miliki. Yaitu dengan cara memenuhi hak karyawan dan memperhatikan lingkungan kerja agar tetap nyawan dan bersih. Sehingga dengan begitu karyawan akan merasa senang dalam menyelesaikan pekerjaanya dan kinerja karyawan semakin meningkat.

\section{DAFTRA PUSTAKA}

Asnawi, M. A. (2019). Kinerja Karyawan Perseroan Terbatas (Z. Fachrussyah (ed.1). CV. Artha Samudra.

Dewi, D. P., \& Harjoyo. (2019). Manajemen Sumber Daya Manusia. In E. Junaedi (Ed.1, Issue 1). UNPAMPress.

Enny, W. M. (2019). Manajemen Sumber Daya Manusia (M. W Erma ; Ed.1). UBHARA Manajemen Press.

Masram, \& Mu'ah. (2017). Manajemen Sumber Daya Manusia. In Zifatama Publisher (Ed.1). Zifatama Publisher. 


\section{Reslaj: Relicion Education Social Laa Roiba Journal}

Volume 4 Nomor 3 (2022) 516-527 P-ISSN 2656-274x E-ISSN 2656-4691

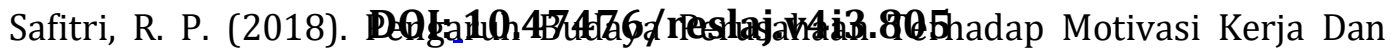

Dampaknya Pada Kinerja Karyawan. Journal of Management Review, 2(2), 198. https://doi.org/10.25157/jmr.v2i2.1795

Sinambela, L. P. (2018). Manajemen Sumber Daya Manusia (Suryani (ed.3), Vol. 148). PT Bumi Aksara.

Sugiyono. (2017). Metode Penelitian Kuantitatif, Kualitatif Dan R\&D (ed.23) CV.Alfabeta

Sutrisno, E. (2017). Manajemen Sumber Daya Manusia (Cetakan ke-1). KENCANA.

Tuala, R. P. (2020). Budaya Organisasi dan Kepemimpinan Di Lembaga Pendidikan Islam. In Pustaka Media (Ed.1, Vol. 53, Issue 1). Pustaka Media.

Wekker, I. S. (2019). Metode Penelitian Sosial (I. Fatria (ed.1)). CV. Adi Karya Mandiri. Widyanti, R. (2019). Perilaku Organisasi (Teori Dan Konsep) (Basuki (ed.1)). Universitas Islam Kalimantan MAB Banjarmasin. 